\title{
The role of wetlands in the changing ecophysiology and distribution of plant species: a comprehensive review
}

\author{
Musyimi D.M \\ Maseno University, Faculty of Science, Department of Botany and Horticulture \\ P.O BOX 333, Maseno- Kenya.
}

\begin{abstract}
Wetlands are important ecosystems globally. Changes in plant species physiology, species composition, species distribution and phenology have occurred with changes and modifications of wetland ecosystems. This paper reviews the role of wetlands in relation to the ecophysiology of plants and extend to which the current change in wetland ecosystems has affected growth, physiology, distribution and performance of wetland plant species. The paper reports on the past and the future of our current wetland ecosystems.
\end{abstract}

Keywords: Ecophysiology, ecosystems, eutrophication, nutrients, wetland conservation.

\section{INTRODUCTION}

\section{What are wetlands?}

Wetlands are transitional areas between land and water and are distinguished by wet soils, plants that are adapted to wet soils and a water table depth that maintains these characteristics (Kamau, 2009). The ability of wetlands to transform and store organic matter and nutrients has resulted in wetland being described as the kidneys of the landscape (Brix, 1994). This ability is being exploited in wetlands used for water quality improvement (Brix, 1994).Wetlands are areas that are wet for long enough periods that the plants and animals living in or near them are adapted to and often dependent on wet conditions for at least part of their life cycle (Anonymous, 1996). Wetlands cover nearly $10 \%$ of the earth's surface of which $2 \%$ are lakes, $30 \%$ bogs, $26 \%$ fens, $20 \%$ swamps and 15\% floodplains (Anonymous, 1999). Wetlands are highly dependent on ground water levels, and so changes in climatic conditions that affect water availability highly influence the nature and function of specific wetlands. The annual cumulative period between which these wetlands become effectively flooded and when they are completely drawn down following drought is regarded as the hydroperiod (Gathumbi et al., 2005).

Global climate change has been shown to influence the distribution and functions of wetlands by altering their hydrological regimes (changing water availability and depth, duration, frequency, and season of flooding) outside their normal range (Galbraith and Huber-Lee, 2005). Climatic parameters, landscape factors, seasonal availability of water and nutrients, as well as soil characteristics determine largely the production potential of a wetland. The vulnerability of wetland resources depends on the direction and magnitude of human activities, and climate changes. Global warming and its possible effects on wetlands is a major concern to the general public today.

Functions of wetlands: Wetlands provide important ecosystem functions. Ecosystem functions are defined as the capacity of natural processes and components of natural or semi-natural systems to provide goods and services that satisfy human needs" (De Groot, 1992). Wetlands are important ecosystems from perspectives of regional biological diversity, hydrologic functioning, and productivity (Gathumbi et al., 2005).

Wetlands are regulators of water quantity and water quality (Nzengy'a and Wishitemi, 2001). Natural and constructed wetlands can remove large amounts of nutrients and suspended solids from surface water flowing through them (Beadle et al., 2004; Huang and Pant, 2009).Wetlands can remove and store large amounts of $\mathrm{N}$ and later released to the ecosystems mostly in organic forms. Previous studies in Kenya have revealed that Cyperus papyrus swamps are efficient in nutrient removal for the purpose of wastewater quality improvement (Nzengy'a and Wishitemi, 2001). Nitrogen retention in the wetlands occurs through a variety of mechanisms including filtration, adsorption, ion exchange, biological assimilation, and denitrification (Lee and Caporn, 1998; Huang and Pant, 2009). Several types of wetlands are known to act as hydrological buffers. 
For example, floodplain wetlands store water when rivers over-top their banks, reducing flood risk downstream. Wetlands not only regulate the quantity of water flow but also regulate its quality (Anonymous, 1999).

Wetland plants are known as important wetland regulators since they remove pollutants and excessive mineral nutrients from the water (Romero et al., 1999). Nitrogen can be removed from wetland waters by bacterial denitrification and plant accumulation (Beadle et al., 2004; Huang and Pant, 2009). Nitrate uptake by aquatic plants acting as, 'temporary' sinks, may be important in young wetlands or trivial in mature vegetation stands (Huang and Pant, 2009). Constructed freshwater wetland can provide reliable tertiary treatment of municipal wastewater (Nzengy'a and Wishitemi, 2001). The accomplishment of wetlands in the removal of nutrients, trace metals, organics and pathogens is attributed to diverse wetland processes such as sedimentation, filtration, chemical precipitation, adsorption, microbial interaction and uptake by vegetation (Nzengy'a and Wishitemi, 2001).

Many components of wetland ecosystems provide resources for direct human consumption including: water for drinking, fish and fruit to eat, reeds for thatching houses and handcrafts, timber for construction, peat and fuelwood for fire (McAllister et al., 1997). Harvesting of wetland goods, while respecting the production rate and the regenerative capacity of each species, can provide significant benefits to society (Acreman and Hollis, 1996).

Recreational uses of wetlands include fishing, sport hunting, bird watching, photography, and water sports. Tourism is one of the leading income generating industries globally and the economic value of these wetlands can be considerable. Maintaining wetlands and capitalizing on wetland values can be a valuable alternative to more disruptive uses and degradation of these ecosystems.

\section{Eutrophication and ecophysiology of wetland} plants: Eutrophication is a natural phenomenon of ageing in lakes, where organic material gradually accumulates in the lake basin during the geological history of the lake (UNEP, 1993). Eutrophication can also be defined as the enrichment of water body with plant nutrients particularly nitrates and phosphates, resulting in the nuisance of algal blooms and aquatic macrophytes (Awange and Ong'ang'a, 2006).
Increased concentrations of nutrients through runoff from agricultural land and changes in land use which increase run off contribute to eutrophication (Nzengy'a and Wishitemi, 2001). There are usually two consequences of eutrophication on plant communities: (1) an increase in emergent plant biomass and (2) a decrease in plant species diversity at high production levels (McJannet et al., 1995). The numbers of rare plants in wetland communities are also known to decrease as nutrient supply increases (McJannet et al., 1995). Changes in species composition, loss of overall plant diversity, conversion of a unique flora to one dominated by a few common species, and replacement of native species by exotics have been reported in connection with nutrient enrichment in several types of wetlands (Verhoeven and Schmitz, 1991).

Comparative studies have shown that high species diversity is frequently associated with low nutrient status and that species-rich wetlands typically have moderate productivity and standing crop (Verhoeven and Schmitz, 1991). Natural or constructed wetlands are used for removal of pollutants from wastewater or for treatment of storm water runoffs from agricultural lands and other non-point sources (Romero et al., 1999; Huang and Pant, 2009). The ability of vegetation to remove nutrients and pesticides from water is related to plant productivity, which is directly dependent upon carbon fixation. Increased productivity is generally accompanied by greater total nutrient sequestration, and the larger plants resulting from greater productivity provide a large surface area for mechanical and biological interactions with water (Pierce et al., 2007).

The construction of wetlands to reduce the amount of pollutants and nutrients from runoff and waste waters from different sources has become more common in recent years, as a measure to prevent the pollution and eutrophication of the recipient water bodies (Huang and Pant, 2009). Constructed wetlands have been successfully used to retain nutrients from treated wastewaters (Gale et al., 1993; Romero et al., 1999). Macrophytes remove pollutants by (i) directly assimilating them into their tissues, (ii) providing a suitable environment for microbial activity and (iii) slowing down water movement flow rates and thereby allowing sedimentation to take place (Nzengy'a and Wishitemi, 2001). Wetlands may be an integral part of integrated riparian management systems and are highly efficient at denitrification because of their large quantities of organic sediments and decaying plant material (Schultz et al., 1994). 
Future increases in the nutrient enrichment of wetlands are expected to have a marked influence on plant physiology and ecosystem functioning (Huang et al., 2009). Reducing pollution, avoiding vegetation removal, and protecting wetland biological diversity and integrity are important activities to maintain and improve the resiliency of wetland ecosystems so that they continue to provide important services under changed climatic conditions (Kusler et al., 1999).

Within-stand cycling of nutrients is an important feature of wetland systems that provides a basis for understanding their nutrient status, productivity, and degree of eutrophication (Gathumbi et al., 2005). Little is known about the combined effects of climate change with those human activities already influencing lakes and rivers. The influence of climate change on water quality issues such as eutrophication is unclear, particularly because many of the climate-influenced processes leading to eutrophication (e.g., precipitation, snow melt, ice cover, runoff, thermal stratification) have interacting and often opposing effects. Thus, effects of climate change on nutrient recycling will most likely be sitespecific and could lead to either a greater or reduced susceptibility to eutrophication.

A major challenge in predicting plant responses to elevated $\mathrm{CO}_{2}$ is understanding the complex relationships between these effects and other factors, especially nutrient availability, which plays a central role in plant growth (Causin et al., 2006). Numerous observations show that growth responses to elevated $\mathrm{CO}_{2}$ are lessened or even eliminated under low $\mathrm{N}$ nutrition (Causin et al., 2006). This effect is the result of the coordination that exists between $\mathrm{C}$ and $\mathrm{N}$ regulatory systems in the plant. The increase of the content of nitrogen and phosphorus in wetlands plays a major part in problems of eutrophication (Rozema and Leendertse, 1991).

Species with particular adaptations can be categorised according to life-form, life-history or functional type (McJannet et al., 1995; Stohgren., 2001). A good approach to scientific research with wetland plants is to consider the requirements of particular species, their acquisition and use of resources and the plant response to natural environmental stresses such as excessive fertilization. It may be differences in the abilities of the plants to acquire resources and cope with nutrient stress that determines their distribution, rather than changes in the availability of resources or the severity of a particular abiotic factor. Actually it is the combination of both changing abiotic factors and plant adaptation that determines the plant growth preferences. This approach requires extensive research relating species specific physiology to environmental conditions (ecophysiology). A greater understanding of the response of various wetland plant species to nutrient availability will enable us to predict the future responses of the entire groups of species to wetland nutrient enrichment or eutrophication (Huang and Pant, 2009) and hence plan for future wetland conservation and restoration.

Nutrient dynamics and impact on wetland plant species: Land use practices such as agriculture exert a major influence on plant productivity, soil and plant nutrient content, and within-stand nutrient cycling in wetlands (Gathumbi et al., 2005). Nutrients create long term problems to wetland ecosystems (Oketch, 2006). Supply of mineral nutrients plays a major role in distribution of plants. An excess of minerals may result in toxic reactions and may thus be decisive for the occurrence of plants in natural communities (Janiesch, 1991).

Vegetative wetlands can be effective at immobilizing, storing and transforming chemical inputs from uplands (Schultz et al., 1994). Use of inorganic fertilizers associated with agricultural activities is known to increase nutrients in sediments and surface waters and overland flow (Qualls and Richardson, 1995; Gathumbi et al., 2005). These human activities may change the degree of nutrient transformations within the wetlands (Qualls and Richardson, 1995). To maintain the typical species composition of wetlands and their rare species, all influences resulting in eutrophication need to be addressed (Pauli et al., 2002).

Changes in pasture land use practices also lead to alteration in wetland plant community composition and structure and seasonal net primary productivity, which has a direct impact on within-stand nutrient cycling (Gathumbi et al., 2005). Nitrogen is one of the most pervasive of the chemical non-point source (NPS) pollutants. Field studies have shown that $P$ deficiency induced by $\mathrm{N}$ enrichment increases root turnover and decreases nutrient retention by the vegetation (Güsewell et al., 2003). Data from the literature indicate that nutrient retention by wetland plants depends on the type of nutrient limitation (Güsewell et al., 2003). Species composition influences nutrient retention of ecosystems because individual species differ in their tissue nutrient quality (Tilman et al., 1997; Evans and Poorter, 2001).Developing an understanding of how species respond to the effects of human activities on 
wetlands is essential to predicting the future impacts of human influence on both species composition and ecosystem function.

Studies have examined environmental effects on species performance (Casanova and Brock, 2000), and competitive dynamics (Keddy et al., 2000), but few studies have combined the effects of environmental conditions such as climate change and nutrient enrichment to predict species composition. Many genetic and environmental factors influence the species composition of a particular wetland, thus linking species composition to particular environmental conditions is difficult.

Increased fertilizer use, particularly $\mathrm{N}$, in modern agriculture has increased concentrations of nutrients in both ground and surface waters (Gathumbi et al., 2005). Nutrient enrichment increases plant available nutrients, potentially shifting competitive advantages to different species and altering species composition (McJannet et al., 1995). A shift in species composition to more productive, aggressive species may alter the nutrient cycling and productivity of the wetland ecosystems.

Many changes are typical of nutrient enrichment, including increased biomass production, dominance of faster growing plant species, accelerated $\mathrm{N}$ cycling and reduced $\mathrm{N}$ retention (Rochette et al., 2004). Croplands contribute $43 \%$ of the annual nitrogen input to surface waters while pasture and rangelands contribute 25\% (Schultz et al., 1994). Despite the magnitude of these estimates, there is paucity of knowledge on the effects of excess nutrients on the ecophysiology of growth and photosynthesis of plants in wetlands.

Plants can assimilate and immobilize nutrients such as nitrogen and phosphorus (Bolan and Adriano, 2001) as well as heavy metals and pesticides (Sadik et al., 1987; Schultz et al., 1994; Prasad, 2004). Microbial processes are important in reducing Nonpoint sources of pollution in the landscape. Nitrogen and other nutrient dynamics during decomposition of litter is complex, as the nutrients often occur in different forms and are subject to various transformations (Hall et al., 2006). Bross et al. (1995) observed a temporary increase in $\mathrm{N}$ concentration during decomposition, because of $\mathrm{N}$ immobilization during early biomass loss. Generally the concentration of nutrients is found to decrease with depth, the highest levels in the litter and a sharp decrease down the mineral horizon (Gupta and Rorison, 1975). The content of phosphorus in wetlands has greatly increased as a result of discharge of phosphates from rivers. In an experimental study where application of sewage sludge to the Great Sippe Wisset salt marsh in Northern America was done, plant biomass increased significantly in the upper and lower parts of the salt marsh (Rozema and Leendertse, 1991). The tall form of Spartina alterniflora in the lower parts of the salt marsh increased strongly with nutrient enrichment (Rozema and Leendertse, 1991). In addition, ecological processes and biogeochemical cycles (especially the $\mathrm{N}$ cycle) are currently disturbed by human activities. Consequently, it has become necessary to improve the scientific knowledge concerning the characteristics of mineral $\mathrm{N}$ uptake by the major species of the wetland community. It is especially important to understand the dynamics of wetlands processes and develop predictive methods to determine optimal widths and management intensities needed to increase nutrient recycling and reduce negative effects on the wetland's ecosystem functions.

A biotic environment related to plant adaptations: Concerns about the rising atmospheric $\mathrm{CO}_{2}$ levels have prompted considerable interest in recent years regarding the sink potential of soil organic carbon (SOC). Elevated $\mathrm{CO}_{2}$ increases biomass production in plants (Centritto et al., 2002). The increase of atmospheric $\mathrm{CO}_{2}$ concentration is expected to enhance photosynthesis, thus resulting in increased growth and yield of many plants. Past research has found that elevated $\mathrm{CO}_{2}$ increases the growth of most plants, due primarily to increased rates of photosynthesis, altered carbon portioning, and increased water and nutrient use efficiencies (Smith et al., 2008).

Increased atmospheric concentrations of $\mathrm{CO}_{2}$ and other greenhouse gases will cause an increase in mean global temperature by $1-3.5^{\circ} \mathrm{C}$ and is likely to increase evapotranspiration and changes in regional precipitation (Tans, 1993). The pattern and frequency of stomata on any leaf surface are under tight genetic control, but may be modified by environmental parameters such as the availability of $\mathrm{CO}_{2}$ (Croxdale, 2000). Environmental conditions affect stomatal density and this has implications for plant development. Collection of data on stomatal densities from sites which have experienced environmental pollution can provide a baseline against which to assess anthropogenic impacts on these species elsewhere (Zarinkamar, 2007). This has potential to facilitate appropriate monitoring and analysis of 
environmental changes, using stomatal characteristics as an indicator of physiological and genetic response (Zarinkamar, 2007).

A decline in stomatal density would be expected to result from expansion of epidermal cells without the formation of new stomata. Stomatal conductance depends on the density of stomata on the leaf and on their aperture opening, which controls diffusion through individual stomata. Stomatal conductance is decreased by elevated atmospheric $\mathrm{CO} 2$ concentration (Causin et al., 2006). Stomates are sensitive to environmental stress and will usually close during times of stress (Maricle et al., 2007). A decrease in stomatal conductance reduces incoming $\mathrm{CO} 2$ and thus can reduce photosynthesis rates (Maricle et al., 2007). Stomatal closure causes a decrease in internal $\mathrm{CO}_{2}$ concentration. Subsequently, a concomitant decline in photosynthesis results from the diminished availability of $\mathrm{CO}_{2}$ for carbon fixation. Reduction of $\mathrm{CO}_{2}$ concentration increases the amount of harmful reactive oxygen species within the leaf due to ongoing light reaction, which leads to senescence and even death of the plant (Kuan-Hung et al., 2006).

Physiological changes associated with environmental stress in crops and pastures include a reduction in photosynthetic rate. Flood-induced decrease in photosynthetic rate has been associated with a reduction in Rubisco activity, interpreted as an early indicator of flooding stress. Influences of rising global $\mathrm{CO}_{2}$ concentration and increasing nutrient levels on plant growth and ecosystem function have become major concerns, but how photosynthesis changes with $\mathrm{CO}_{2}$ and excessive nutrition in wetland plant species is poorly understood.

The atmospheric concentration in $\mathrm{N}_{2} \mathrm{O}$ is increasing at a rate of $0.25 \%$ annually (Hall et al., 2006). Agricultural sources are estimated to emit approximately $80 \mathrm{mg} \mathrm{N}_{2} \mathrm{O}-\mathrm{N} \mathrm{yr}^{-1}$ or $60 \%$ of the total anthropogenic emissions (Hall et al., 2006). These $\mathrm{N}_{2} \mathrm{O}$ emissions are largely attributed to nitrification and denitrification of $\mathrm{N}$ that is added to the soil to sustain crop productivity (Kamara et al., 1997). Wetlands can provide beneficial functions and minimize adverse effects such as $\mathrm{N}_{2} \mathrm{O}$ emissions to the atmosphere (Lee and Caporn, 1998; Huang and Pant, 2009).

Under natural conditions in seasonal environments, nutrient levels may vary during the growing season and may decline gradually as a result of plant uptake and leaching. Element accumulation by plants typically proceeds more rapidly during growth than with carbon accumulation, although there is considerable variation in relative accumulation rates (Benner and Bazzaz, 1988). Accumulation and distribution of carbon and other elements can be affected by physiological and morphological constraints imposed by plant development (Benner and Bazzaz, 1988). Plants enrich the top soil through litter fall, thus acting as net to trap nutrients which otherwise would be leached down the profile (Kanmegne et al., 1999).

With increased diversification in industrialization and extensive use of metal-based fertilizers, the concentrations of metal pollutants in wetlands continue to rise through natural run off. Presence of metal pollutants in wetland ecosystems is known to disturb the delicate balance of the ecosystems (Ipinmoroti, 1993; Bais et al., 2006).

Invasive species have devastated many of the world's wetland ecosystems (Kourtev, 2003), due to a combination of anthropogenic alteration and nutrient enrichment of wetlands. Invasive plants have higher rates of carbon assimilation and/or water use efficiency relative to native plant species, which may contribute to their spread (McDowell, 2002). For plants, with a high rate of net carbon assimilation can result in higher biomass accumulation, favouring future growth and reproduction as well as competitive status (Brock and Galen, 2005). Studies indicate that elevated $\mathrm{CO}_{2}$ will stimulate the growth and competitiveness of invasive plants (Froud-Williams, 1996), perhaps to a greater degree than other plant species because of their ability to rapidly adapt to new environments (McDowell, 2002). Currently, very little effort has been focused on obtaining empirical data to determine the extent of increased nutrition by wetland plant species and how this might impact the management of these species in a changing global environment. Therefore, it is important to understand how wetland plant species will be impacted by excess nutrients in their natural ecosystems. The growing interest in trees and forests under the influence of environmental pollution and changing global climate makes it desirable to select one or a few plant species to study more intensively (Posthumus, 1991).

\section{CONCLUSIONS}

Future increases in the nutrient enrichment of wetlands are expected to have a marked influence on plant physiology and ecosystem functioning. The review of the role of wetlands in the ecophysiology 
and distribution of wetland plant species is necessary in understanding major challenges facing the current ecosystems and hence predicting the future state of wetland ecosystems. The description of ecophysiological characteristics of wetland plants and other factors that determine their distribution by observation of the past and present situations that are similar to the expected future global environmental changes are needed to understand the fate of these wetland ecosystems.

\section{REFERENCES}

Acreman M.C. and Hollis G.E. (Eds). (1996). Water management and wetlands in sub-Saharan Africa. IUCN, Gland (Switzerland), 249 pp.

Anonymous. (1996).Water for the environment: wetlandsfacts

about wetlands.http://www.dlwc.nsw.gov.au/care/wetlands/fa cts/whatis.html).

Anonymous. (1999). Exploring collaboration between the Convention on Wetlands (Ramsar, Iran, 1971) and the UN Framework Convention on Climate Change website: http://www. ramsar.org, accessed January 2010

Awange J.L. and Ong'ang'a O. (2006). Lake Victoria: Ecology, resources, environment. SpringerVerlagBerlin, Heidelberg Newyork Pp, 354.

Bais H.P., Weir T.L., Perry L.G., Gilroy S. and Vivanco J.M. (2006). The role of root exudates in the rhizosphere interactions with plants and other organisms. Annual Review of Plant Biology 57: 233-266.

Beadle J.V., Holland M.M., Moore M.T. and Cooper C.M. (2004). Nutrient uptake by two common freshwater wetland plants [Abstract]. INTERCOL (International Wetlands Conference).p. 26

Benner B.L. and Bazzaz F.A. (1988). Carbon and mineral element accumulation and allocation in two annual plant species in response to timing of nutrient addition. Journal of Ecology 76: 19-40.

Bolan N. and Adriano D. (2001). Rhizosphere: the twilight zone of the hidden half: soil sediment and water. The magazine of environmental assessment and remediation. AEHSmagazine, December 2001.

Brix H. (1994). Use of constructed wetlands in water pollution control: Historical development, present status, and future perspectives. Journal of Water Science and Technology 30: 209-223.

Brock M.T. and Galen C. (2005). Drought tolerance in the alphine dandelion,Taraxacum ceratophorum (Asteraceae), its exotic congener T.officinale, and interspecific hybrids under natural and experimental conditions. American Journal of Botany 92 (8): 1311 1321.
Bross E.E., Gold M.A. and Nguyen PV. (1995).Quality and decomposition of black locust (Roninia pseudoacacia) and alfalfa (Medicago sativa) mulch for temperate alley cropping systems. Agroforestry Systems 29: 255-264.

Casanova M.T. and Brock M.A. (2000). How do depth, duration and frequency of flooding influence the establishment of wetland plant communities. Plant Ecology 147: 237-250.

Causin H.F., Rufty T.W., and Reynolds J.F. (2006).Gas exchange and Carbon metabolism in two Prosopis species (Fabaceae) from semiarid habitats: Effects of elevated $\mathrm{CO}_{2}, \mathrm{~N}$ supply, and $\mathrm{N}$ source. American Journal of Botany 93(5): 716-723.

Centritto M., Lucas M.E. and Jarvis P.G. (2002). Gas exchange, biomass, whole-plant water-use efficiency and water uptake of peach (Prunus persica) seedlings in response to elevated carbon dioxide concentration and water availability. Tree Physiology 22: 699-706.

Croxdale J.L. (2000). Stomatal patterning in angiosperms. American Journal of Botany 87: 1069-1080.

De Groot R.S. (1992). Functions of nature. Evaluation of nature in environmental planning, management and decision making. Wolters Noordhoff, Deventer (The Netherlands), $315 \mathrm{pp}$.

Evans J.R. and Poorter H. (2001). Photosynthetic acclimation of plants to growth irradiance: the relative importance of specific leaf area and nitrogen partitioning in maximizing carbon gain. Plant, Cell and Environment 2: 755-767.

Froud-Williams R.J. (1996). Weeds and climate change: implications for their ecology and control. Annual Applied Biology 45: 187-196.

Galbraith H.A.P. and Huber-Lee A. (2005). The effects of agricultural irrigation on wetland ecosystems in developing countries: A literature review. Colombo, Sri Lanka, International water management Institute, Comprehensive Assessment Secretariat.

Gale P.M., Reddy K.R. and Graetz D.A. (1993). Nitrogen removal from reclaimed water applied to constructed and natural wetland microcosms. Water Environmental Research 65: 162-168.

Gathumbi S.M., Bohlen P.J. and Graetz D.A. (2005) Nutrient enrichment of wetland vegetation and sediments in Subtropical pastures. Soil Science society of America Journal. 69:539-548.

Gupta P.L. and Rorison I.H. (1975). Seasonal differences in the availability of nutrients down a podzolic profile. Journal of Ecology 63(2): 521-534.

Güsewell S., Bollens U., Ryser P. and Klötzli F. (2003). Contrasting effects of nitrogen, phosphorus and water regime on first-year and second-year growth of 16 
wetland plant species. Functional Ecology 11: 754765.

Hall N.M., Kaya B., Dick J., Skiba U., Niang A. and Tabo R. (2006). Effect of improved fallow on crop productivity, soil fertility and climate-forcing gas emissions in semiarid conditions. Biology and Fertility of Soils 42: 224230.

Huang S. and Pant H.K. (2009). Nitrogen transformation in wetlands and marshes. Journal of Food, Agriculture and Environment 7 (3\&4): 946-954.

Ipinmoroti K.O. (1993). Determination of trace metals in fish, associated water and soil sediments from fish ponds. Discovery and Innovation 5 (2): 135-138.

Jackson M.B. and Colmer T.D. (2005).Response and adaptation by plants to flooding stress. Annals of Botany 96: 501-505.

Janiesch P. (1991).Ecophysiological adaptations of higher plants in natural communities to waterlogging. In: J. Rozema and J.A.C. Verkleij (eds.), Ecological responses to environmental stresses.Kluwer Academic Publishers, Netherlands, pp. 50-60.

Kamara A.Y., Sanginga N., Jutzi S.C. and Chikoye D. (1997). Exclusion of understorey vegetation by some tree species in planted fallows in South- Western Nigeria. Tropentag 1997, Hohenheim. Pp. 107- 113.

Kamau C.G. (2009). Constructed wetlands: potential for their use in treatment of Grey water in Kenya. Msc thesis, Universität zu Kiel, Germany. Pp 77.

Kanmegne J, Duguma B, Henrot J, and Isirimah N.O. (1999). Soil fertility enhancement by planted treefallow species in the humid lowlands of Cameroon. Agroforestry Systems 46: 239-249.

Keddy P.A., Gaudet C. and Fraser L. H. (2000). Effects of low and high nutrients on the competitive hierarchy of 26 shoreline plants. Journal of Ecology 88: 413-423.

Kourtev P.S., Ehrenfield J.G. and Haggblom M. (2003). Experimental analysis of the effect of exotic and native plant species on the structure and function of soil microbial communities. Soil Biology and Biochemistry 35: 895-905.

Kuan-Hung L., Pi-Yu C., Chi-Ming Y., Wen-Ching C., Hsiao-Feng L. and Tsan-Ru C. (2006). The effects of flooding and drought stresses on the antioxidant constituents in sweet potato leaves. Botanical Studies 47: 417-426.

Kusler J., Brinson M., Niering W., Patterson J., Burkett V. and Willard D. (1999). Wetlands and climate change: scientific knowledge and management options. White Paper Institute for Wetland Science and Public Policy, Association of State Wetland Managers / Wetlands International, $27 \mathrm{pp}$.
Lee J.A. and Caporn S.J.M. (1998). Ecological effects of atmospheric reactive nitrogen deposition on seminatural terrestrial ecosystems. New Phytologist 139: 127-134.

Maricle B.R., Lee R.W., Hellquist C.E., Kiirats O. and Edwards G.E. (2007). Effects of salinity on chlorophyll fluorescence and $\mathrm{CO}_{2}$ fixation in $\mathrm{C} 4$ estuarine grasses. Photosynthetica 45 (3): 433-440.

McAllister D.E., Hamilton A.L. and Harvey B. (1997). Global freshwater biological diversity: Striving for the integrity of freshwater ecosystems. Seawind 11(3), 140 pp.

McDowell S.C.L. (2002). Photosynthetic characteristics of invasive and non-invasive species of Rubus (rosaceae). American Journal of Botany 89: 14311438.

Nzengy'a D. M and Wishitemi B. E. L. (2001). The performance of constructed wetlands for wastewater treatment: a case study of splash wetland in Nairobi, Kenya. Hydrol. Process. 15, 3239-3247.

Oketch, M.A. (2006). The potential role of constructed wetlands in protection and sustainable management of lake catchments in Kenya. In: OceanDocs - Africa Kenya - Kenya Marine and Fisheries Research Institute - Conference Papers. Retrieved July 23, 2010, from http://hdl.handle.net/1834/1470

Pauli D., Peintinger M. and Schmid B. (2002). Nutrient enrichment in calcareous fens: effects on plant species and community structure. Basic and Applied Ecology 3 (3): 255-266.

Pierce S.C., Pezeshki S.R. and Moore M.T. (2007). Ditch plant response to variable flooding: A case study of Leersia oryzoides (rice cutgrass). Journal of Soil and Water Conservation 62 (4): 216-225.

Posthumus A.C. (1991). Effects of air pollution on plants and vegetations. In: J. Rozema and J.A.C. Verkleij (eds.), Ecological responses to environmental stresses.Kluwer Academic Publishers, Netherlands, pp. 191-198.

Prasad M.N.V. (2004). Heavy metal stress in Plants. Springer, Pp: 462.

Qualls R.G., and Richardson C.J. (1995). Forms of phosphurus along a nutrient enrichment gradient in the northern everglades. Soil Science 160:183-198.

Rochette P., Angers D.A,, Bélanger G., Chantigny M.H., Prévost D. and Lévesque G. (2004). Emissions of $\mathrm{N}_{2} \mathrm{O}$ from Alfalfa and Soybean Crops in Eastern Canada. Soil Science Society of American Journal 68: 493-506.

Romero J.A., Brix H., Com'ın F.A. (1999). Interactive effects of $\mathrm{N}$ and $\mathrm{P}$ on growth, nutrient allocation and $\mathrm{NH}_{4}$ uptake kinetics by Phragmites australis. Aquatic Botany 64: 369-380. 
Rozema J. and Leendertse P.C. (1991). Natural and manmade environmental stresses in coastal wetlands. In: J. Rozema and J.A.C. Verkleij (eds.), Ecological responses to environmental stresses. Kluwer Academic Publishers, Netherlands, pp. 92-101.

Sadik M.H., Abbas H.H., Abdel-Aziz S.M. and Allam S.M. (1987). Sewage water as a possible source for irrigating sandy soils. In Proceedings of 1st Conference on Agricultural Development Research 1, pp: 206-220.

Schultz R.C., Isenhart T.M. and Colletti J.P. (1994). Riparian buffer systems in crop and rangelands.Agroforestry and sustainable systems: Symposium proceedings August 1994.

Smith K.E., Runion G.B., Prior S.A., Price A.J., Rogers H.H. and Torbert H.A. (2008). Chinese Privet (Ligustrum sinense) in an elevated $\mathrm{CO}_{2}$ environment. Botany Research Journal 1(2): 43-48.

Stohgren T.J., Otsuki Y., Villa C.A., Lee M. and Belnap J. (2001).Patterns of plant invasions: a case example in native species hotspots and rare habitats. Biological Invasions 3: 37-50.

Tans P.P. (1993). Observational strategy for assessing the role of terrestrial ecosystems in the global carbon cycle: scaling down to regional levels. Scaling physiological processes: leaf to globe (ed. By J.R. Ehleringer and C.B. Field), pp: 179-190.

Tilman D., Knops J., Wedin D., Reich P., Ritchie M. and Siemann E. (1997). The influence of functional diversity and composition on ecosystem processes. Science 277: 1300-1302.

UNEP. (1993). United Nations Environment Programme Environmental Data Report 1993/94, Blackwell publishers, Oxford.

Verhoeven J.T.A. and Schmitz M.B. (1991). Control of plant growth by nitrogen and phosphorus in mesotrophic fens. Biogeochemistry 12: 135-148.

Zarinkamar F. (2007). Stomatal observations in dicotyledons. Pakistan Journal of Biological Sciences. 10 (2): 199-219. 